\title{
UJI PENURUNAN KADAR GLUKOSA DARAH OLEH EKSTRAK ETANOL 70\% DAUN BUNCIS (Phaseolus vulgaris L) PADA KELINCI JANTAN YANG DIBEBANI GLUKOSA
}

\author{
Desy Kurniawati, EM Sutrisna, Arifah Sri Wahyuni \\ Fakultas Farmasi Universitas Muhammadiyah Surakarta
}

\begin{abstract}
This research aim to know the descent of blood glucose rate by extract etanol 70\% of bean leaf at male rabbit which induced glucose. Research using the method test glucose tolerance of oral was including category research of sham eksperimental with complete random attempt device of unidirectional pattern. This research use 20 male rabbits which divided in 5 treatment group. Group I given by $\mathrm{CMC} \mathrm{Na} 1 \%$ as negative control, group II given by acarbose suspensi $2,33 \mathrm{mg} / \mathrm{kgBB}$ as positive control, group III, $I \mathrm{~V}$ and $\mathrm{V}$ given by extract etanol $70 \%$ bean leaf with each dose 200, 300 and $450 \mathrm{mg} / \mathrm{kgBB}$. Treatment given at once after test animal induced glucose $50 \%(5 \mathrm{ml} / 1,5 \mathrm{kgBB})$. Glucose blood rate to define every 30 minute, 0 minute until 300 minutes by using method of enzimatik GOD PAP (Glucose Oxidase Phenol Aminoantipyrina Peroxidase), what was later then analysed with one track Anava and continued by test of LSD (Least Significant Diffeerence) with trust level 95\%. Extract etanol $70 \%$ bean leaf with dose 200, 300 and $450 \mathrm{mg} / \mathrm{kgBB}$ have effect descent of blood glucose rate to negative control of CMC Na $1 \%(p=0,000)$ with each percentage descent of blood glucose rate $(\%$ PKGD) 80,88 $\pm 0,93 ; 82,73$ $\pm 0,67$ and $85,32 \pm 0,21$.
\end{abstract}

Keyword: Extract etanol 70\%, bean leaf (Phaseolus vulgaris L), degradation of glucose rate

\section{PENDAHULUAN}

Penyakit Diabetes Mellitus (DM) merupakan salah satu dari beberapa penyakit degeneratif yaitu penyakit akibat fungsi atau struktur dari jaringan atau organ tubuh yang secara progresif menurun dari waktu ke waktu, yang diakibatkan usia atau pilihan gaya hidup (Subroto, 2006). Penyakit DM adalah suatu kumpulan gejala yang timbul pada seseorang akibat meningkatnya kadar gula (glukosa) darah yang disebabkan kekurangan insulin baik absolut maupun relatif, sehingga pengaturan kadar glukosa darah menjadi kacau. Walaupun kadar glukosa darah sudah tinggi, pemecahan lemak dan protein menjadi glukosa (glukoneogenesis) di hati tidak dapat dihambat sehingga kadar glukosa darah semakin meningkat (Soegondo dkk., 2005). Penyakit DM menimbulkan komplikasi antara lain: gangguan ginjal, gangguan penglihatan, gangguan seksual, kerusakan saraf, gangguan peredaran darah, jantung, serta mudah terkena infeksi (Anonim ${ }^{\mathrm{b}}$, 2005).

Jumlah penderita penyakit DM terus meningkat setiap tahunnya. Menurut data yang dipublikasikan dalam jurnal Diabetes Care tahun 2004, penderita diabetes di Indonesia pada tahun 2000 mencapai 8,4 juta orang (Subroto, 2006) dan hasil survey yang dilakukan oleh organisasi kesehatan dunia WHO, Indonesia menempati urutan ke-4 terbesar dengan prevalensi 8,6\% dari total penduduk dalam jumlah penderita penyakit DM (Anonim ${ }^{\mathrm{a}}$, 2005). Meningkatnya prevalensi DM di Indonesia dapat menimbulkan dampak negatif berupa penurunan kualitas Sumber Daya Manusia (SDM) akibat sifat penyakit yang menahun. Pengobatan yang dilakukan tidak murah karena penderita DM harus mengkonsumsi obat dalam jangka waktu yang cukup lama. Padahal obat sintetis kimia (obat konvensional) yang dikonsumsi dan beredar di pasaran cukup mahal.

Indonesia memiliki alam yang menyediakan beragam tanaman obat berkhasiat yang dapat digunakan untuk mengatasi berbagai macam penyakit. Tanaman-tanaman yang diduga berkhasiat untuk pengobatan, sebenarnya telah digunakan secara tradisional (Subroto, 2006). Saat ini penggunaan obat-obatan dari bahan alami (obat herbal) dalam pengobatan semakin meningkat, 
namun bukti ilmiahnya pada umumnya masih sedikit, sementara tuntutan bukti-bukti ilmiah dari pengguna obat tradisional semakin meningkat dengan semakin meningkatnya kesadaran masyarakat akan kesehatan (Suharmiati, 2003).

Tanaman obat terbukti salah satu sumber bahan baku obat DM karena pada tanaman tersebut memiliki senyawa-senyawa yang berkhasiat sebagai antidiabetes mellitus. Buah buncis sudah terbukti memiliki khasiat sebagai antidiabetes yaitu mampu menurunkan kadar glukosa darah (Muhtadi, 1987). Daun buncis memiliki kandungan yang mirip dengan buah buncis (Hutapea, dan Syamsyuhidayat, 1994), sehingga mendorong peneliti untuk mengetahui kemampuan daun buncis dalam menurunkan kadar glukosa darah pada kelinci jantan yang dibebani glukosa dengan menggunakan ekstrak etanol $70 \%$, karena kemungkinan kandungan senyawa yang terdapat dalam daun buncis dapat tersari. Diharapkan penelitian ini dapat memberikan informasi tentang khasiat daun buncis sebagai penurun kadar glukosa darah dengan dasar bukti yang dapat dipertanggungjawabkan secara ilmiah, serta nantinya dapat digunakan sebagai alternatif obat antidiabetes.

\section{METODE PENELITIAN}

Bahan: Subjek uji yang digunakan adalah kelinci jantan albino galur lokal dengan berat badan 1,0-1,9 kg. Bahan-bahan yang digunakan adalah daun buncis muda (daerah Karang Pandan, Tawangmangu), acarbose (Glucobay ${ }^{\mathrm{R}}$, Bayer), aquadest (Brataco), glukosa GOD PAP (DiaSys), D-glukosa monohidrat (E.Merck), CMC Na (teknis), dan EDTA (Laboratorium Biologi Universitas Muhammadiyah Surakarta), dan etanol teknis 70\% (Brataco).

Alat: Dalam penelitian ini alat yang digunakan adalah alat-alat gelas, ayakan no.40 mesh, corong Buchner, kompor, spuit injeksi, kateter, microtube 1,5 ml, mikropipet, yellow tips, blue tips, vortex (maxi mix II), ultrasentrifuse (mini spin ependrof), spektrofotometer visibel (Star Dust FC 15 DiaSys) dan timbangan hewan uji.

Determinasi Tanaman: Determinasi pada tanaman buncis (Phaseolus vulgaris $\mathrm{L}$ ) dilakukan di Balai Penelitian Tanaman Obat (BPTO) Tawangmangu.
Pembuatan Serbuk Daun Buncis: Tanaman buncis diperoleh dari daerah Karang Pandan, Tawangmangu pada bulan Desember 2006. Tanaman buncis yang digunakan adalah yang berusia 2 bulan dengan buah mulai masak. Pengambilan daun buncis dilakukan siang hari saat proses fotosintesis sedang berlangsung. Daun yang dipilih adalah daun muda yang sehat, dan terletak kira-kira 1-5 dari pucuk daun. Daun yang telah terkumpul dicuci air mengalir sampai bersih untuk menghilangkan kotoran berupa tanah, bagian tanaman lain dan bagian tanaman yang rusak. Daun ditiriskan dan dikeringkan untuk mencegah timbulnya bakteri dan kapang.

Pengeringan dilakukan di bawah sinar matahari ditutup kain hitam, untuk mencegah kerusakan kandungan senyawa aktif dalam daun buncis akibat pancaran sinar matahari, karena kain hitam dapat mencegah masuknya sinar matahari namun dapat menyimpan panas, sehingga proses pengeringan berlangsung baik tanpa merusak senyawa kimia dalam daun buncis. Simplisia kering diserbuk dengan blender dan diayak dengan ayakan no.40 mesh. Tujuan pembuatan serbuk adalah untuk memperbesar luas permukaan daun buncis, sehingga kontak antara bahan dan larutan penyari lebih besar dan penyarian berlangsung lebih cepat serta senyawa aktif yang tersari lebih banyak.

Pembuatan Ekstrak Etanol 70\% Daun

Buncis: Pembuatan ekstrak etanol $70 \%$ daun buncis menggunakan cairan penyari etanol teknis $70 \%$. Metode penyarian yang digunakan adalah remaserasi, yaitu maserasi secara berulang. Sebanyak 420,900 gram serbuk simplisia disari dengan etanol teknis 70\%. Volume etanol sebesar 5 kali berat simplisia yang digunakan. Kemudian rendaman didiamkan selama 3 hari (3X24 jam) sambil sesekali diaduk. Filtrat diambil melalui penyaring dengan menggunakan corong Buchner dan dienapkan selama 2 hari. Setelah dienaptuangkan, penyari diuapkan hingga diperoleh ekstrak kental etanol. Ampas dianginanginkan sampai kering dan direndam kembali dengan etanol $70 \%$ sesuai dengan volume awal penyari yang digunakan. Hal tersebut dilakukan berulang sampai 3 kali berturut-turut untuk pengambilan sari yang maksimal.

Penentuan Operating Time (OT): Sebanyak 10,0 $\mu \mathrm{l}$ aquadest ditambah 1000,0 $\mu \mathrm{l}$ reagen Glucose Oxidase Phenol Amino antipyrin 
Peroxidase (GOD PAP) DiaSys, yang digunakan sebagai blangko. Sebagai standart digunakan 10,0 $\mu \mathrm{l}$ glukosa baku dari DiaSys ditambah 1000,0 $\mu \mathrm{l}$ reagen GOD PAP (DiaSys), kemudian diinkubasi pada suhu kamar $\left(25-30^{\circ} \mathrm{C}\right)$. Absorbansinya dibaca dengan menggunakan spektrofotometer visibel (Star Dust FC) pada panjang gelombang $500 \mathrm{~nm}$ (berdasarkan panjang gelombang yang tertera pada leaflet reagen glukosa GOD PAP DiaSys) dan pada menit ke $5,10,15,20,25,30,35,40$, $45,50,55,60$.

\section{Penentuan Panjang Gelombang} Absorbansi Maksimum: Sebanyak 10,0 $\mu \mathrm{l}$ aquadest ditambah 1000,0 $\mu \mathrm{l}$ reagen GOD PAP (DiaSys) yang digunakan sebagai blangko. Sebagai standart digunakan $10,0 \mu \mathrm{l}$ glukosa baku dari DiaSys ditambah 1000,0 $\mu$ l reagen GOD PAP (DiaSys), kemudian diinkubasi pada suhu kamar $\left(25-30^{\circ} \mathrm{C}\right)$ selama operating time. Absorbansinya dibaca dengan menggunakan spektrofotometer visibel (Star Dust FC) pada panjang gelombang 405, 500, 546, 578, dan 630 $\mathrm{nm}$. Panjang gelombang maksimum ditentukan untuk mendapatkan absorbansi yang maksimum.

Pembuatan Larutan Glukosa 50\%: Sebanyak 50,0 gram D-glukosa monohidrat dilarutkan sedikit demi sedikit dalam air panas sampai volume 100,0 ml sambil diaduk.

Pembuatan Larutan CMC Na 1\%: Sebanyak 1,0 gram CMC Na dilarutkan dalam aquadest sambil dipanaskan dan diaduk sampai terbentuk suspensi, kemudian ditambahkan aquadest sampai volume 100,0 ml.

Perhitungan Dosis Acarbose: Perhitungan dosis acarbose untuk kelinci didasarkan pada dosis terapi peroral sekali untuk manusia. Acarbose yang digunakan ialah glucobay ${ }^{\mathrm{R}}$. Dosis untuk manusia berat $70 \mathrm{~kg}$ sekali minum $=50 \mathrm{mg}$. Konversi dosis manusia $70 \mathrm{~kg}$ ke kelinci $1,5 \mathrm{~kg}=0,07$. Dosis untuk kelinci $1,5 \mathrm{~kg}$ sekali minum adalah $3,5 \mathrm{mg}$ atau $2,33 \mathrm{mg} / \mathrm{kgBB}$.

Penetapan Peringkat Dosis: Penetapan peringkat dosis ekstrak etanol $70 \%$ daun buncis dengan trial and error sebesar $200 \mathrm{mg} / \mathrm{kgBB}, 300$ $\mathrm{mg} / \mathrm{kgBB}$ dan $450 \mathrm{mg} / \mathrm{kgBB}$.

Uji Penurunan Kadar Glukosa Darah: Hewan uji dikelompokkan menjadi 5 kelompok perlakuan. Setiap kelompok terdiri dari 4 ekor. Subyek uji dipuasakan 12-18 jam dan tetap diberi minum ad libitum, kemudian mendapat pembebanan glukosa $50 \%(5 \mathrm{ml} / 1,5 \mathrm{kgBB})$ dan seketika diberi perlakuan secara oral dengan dosis tunggal sebagai berikut: a) Kelompok I kontrol negatif diberi larutan $\mathrm{CMC} \mathrm{Na} \mathrm{1 \% ,b)} \mathrm{Kelompok}$ II kontrol positif diberi suspensi acarbose dosis $2,33 \mathrm{mg} / \mathrm{kgBB}$ dalam CMC Na 1\%, c) Kelompok III diberi ekstrak etanol $70 \%$ daun buncis dosis $200 \mathrm{mg} / \mathrm{kgBB}$, d) Kelompok IV diberi ekstrak etanol $70 \%$ daun buncis dosis $300 \mathrm{mg} / \mathrm{kgBB}$ dan e) Kelompok V diberi ekstrak etanol $70 \%$ daun buncis dosis $450 \mathrm{mg} / \mathrm{kgBB}$.

Cuplikan darah diambil dari vena lateralis telinga kelinci pada menit ke $0,30,60,90,120$, 150, 180, 210, 240, 270, dan 300. Kadar glukosa darah ditetapkan dengan metode enzimatis yang menggunakan pereaksi GOD PAP (DiaSys).

Penetapan Kadar Glukosa Darah: Kadar glukosa darah ditetapkan secara enzimatis dengan reagen GOD PAP (DiaSys). Cuplikan darah diambil dari vena lateralis telinga kelinci, ditampung dalam microtube 1,5 $\mathrm{ml}$ yang telah diberi antikoagulan Ethylen Diamin Tetra Acetic acid (EDTA), dan di vortex serta disentrifuge dengan kecepatan 2.500 rotasi per menit (rpm) selama 10 menit, selanjutnya dipersiapkan komposisi seperti yang disajikan pada Tabel 1 .

Tabel 1. Komposisi Sampel, Standart, dan Blanko yang Dianalisis pada Penetapan Kadar Glukosa Darah

\begin{tabular}{lccc}
\hline \multirow{2}{*}{ Komposisi Bahan } & Sampel & Volume Pengambilan $(\mu \mathrm{l})$ & Blanko \\
\cline { 2 - 4 } & 10 & Standart & - \\
\hline Darah & - & 10 & 10 \\
Glukosa standart & - & - & 10 \\
Aquadest & & \\
$\begin{array}{l}\text { Ditambah Reagen GOD PAP 1000 }(\mu 1) \text {. Diinkubasi pada suhu kamar }\left(25-30^{\circ} \mathrm{C}\right) \text { selama } 10-15 \text { menit. Kemudian serapan dibaca } \\
\text { dengan spektrofotometer (Star Dust FC) pada panjang gelombang 500 nm. }\end{array}$
\end{tabular}

Cara Analisis: Absorbansi yang diperoleh dari hasil pembacaan pada panjang gelombang $500 \mathrm{~nm}$ dengan operating time 10-15 menit digunakan untuk menghitung kadar glukosa darah. Konsentrasi glukosa standart adalah 100 $\mathrm{mg} / \mathrm{dl}$. Rumus yang digunakan untuk menghitung kadar glukosa darah: 
$\operatorname{Kadar}(\mathrm{mg} / \mathrm{dl})=\frac{\text { Absorbansi Sampel }}{\text { AbsorbansiStandart }} \times$ Kadar glukosa standart $(\mathrm{mg} / \mathrm{dl})$

$$
\frac{\mathrm{AUC}_{0-\mathrm{n}}}{2}=\mathrm{t}_{1}-\mathrm{t}_{0} \times \frac{\left(\mathrm{C}_{0}+\mathrm{C}_{1}\right)}{2}+\mathrm{t}_{2}-\mathrm{t}_{1} \times \frac{\left(\mathrm{C}_{2}+\mathrm{C}_{1}\right)}{2}+\ldots+\mathrm{t}_{\mathrm{n}}-\mathrm{t}_{\mathrm{n}-1} \mathrm{x}\left(\mathrm{C}_{\mathrm{n}}+\mathrm{C}_{\mathrm{n}-1}\right)
$$

Data $\mathrm{AUC}_{0-300}$ dihitung dengan rumus persentase penurunan kadar glukosa darah (\%PKGD) yaitu:

$$
\% \mathrm{PKGD}=\frac{\mathrm{AUC}_{0-300} \text { kontrol negatif }-\mathrm{AUC}_{0-300} \text { kelompok perlakuan }}{\mathrm{AUC}_{0-300} \text { kontrol negatif }} \times 100 \%
$$

Data $\mathrm{AUC}_{0-300}$ yang diperoleh dianalisis dengan Anava satu jalan dan dilanjutkan dengan uji Least Significant Difference (LSD) dengan menggunakan taraf kepercayaan $95 \%$.

\section{HASIL DAN PEMBAHASAN}

Ekstrak Etanol 70\% Daun Buncis: Penyarian menghasilkan sari etanol, yang kemudian diuapkan hingga menjadi ekstrak kental etanol. Ekstrak etanol yang diperoleh dari 420, 900 gram serbuk simplisia adalah sebanyak 88,11 gram. Rendemen yang diperoleh dari ekstrak kental etanol adalah sebesar 20,974 \%.

Penetapan Operating Time (OT): Penetapan operating time dimaksudkan untuk mengetahui waktu larutan seny awa berwarna merah (kuinonimin) terbentuk, sehingga memberikan absorbansi stabil yang dimungkinkan reaksi warna antara glukosa dengan reagen GOD PAP sudah sempurna membentuk senyawa akhir kuinonimin. Reaksi pembentukan senyawa kuinonimin disajikan pada Gambar 1.<smiles>OC[C@H]1O[C@H](O)[C@@H](O)[C@H](O)[C@H]1O</smiles>

Glukosa

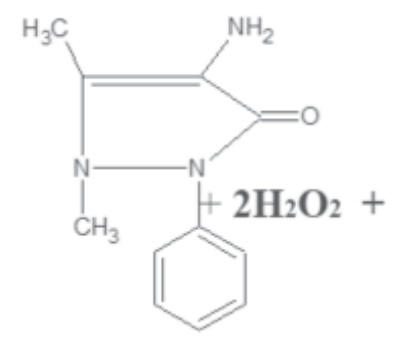

4-amino-antipirin

Gambar 1. Pembentukan Senyawa Berwarna Merah (Kuinonimin) dari Substansi Awal Glukosa dengan Reagen GOD PAP (Chaplin, 1996, cit Rezeki, 2005) 
Tabel 2. Absorbansi Glukosa dengan Pereaksi GOD PAP (DiaSys) pada Berbagai Waktu Inkubasi

\begin{tabular}{cc}
\hline Waktu (Menit) & Absorbansi \\
\hline 0 & 0,061 \\
5 & 0,317 \\
10 & 0,354 \\
15 & 0,354 \\
20 & 0,344 \\
25 & 0,353 \\
30 & 0,353 \\
35 & 0,352 \\
40 & 0,347 \\
45 & 0,353 \\
50 & 0,348 \\
55 & 0,347 \\
60 & 0,357 \\
\hline
\end{tabular}

Metode penetapan kadar glukosa darah yang digunakan adalah metode enzimatis. Reaksi antara glukosa dan GOD PAP terjadi secara bertahap. Tahap pembentukan senyawa kuinonimin dari substansi awal glukosa dengan senyawa di dalam reagen yaitu pembentukan asam glukonat dan senyawa lain hidrogen peroksidase $\left(\mathrm{H}_{2} \mathrm{O}_{2}\right)$ dari glukosa dengan katalis enzim glukosidase (GOD), dan pembentukan senyawa kuinonimin dari fenol dan 4-amino-antipirin, dengan katalis enzim peroksidase. Pembentukan kuinonimin dapat dilihat pada Gambar 3.

Hasil penetapan OT pada Tabel 2 menunjukkan bahwa pada menit ke 10-15 memperlihatkan absorbansi yang stabil. Profil kurva OT merupakan absorbansi dari larutan standart pada menit ke 0 sampai 60 pada panjang gelombang $500 \mathrm{~nm}$.

Panjang Gelombang Absorbansi Maksimum: Penetapan panjang gelombang absorbansi maksimum dimaksudkan untuk menetapkan panjang gelombang tertentu yang menghasilkan absorbansi maksimum, sehingga dimungkinkan diperoleh kepekaan yang maksimum.

Tabel 3. Absorbansi Glukosa dengan Pereaksi GOD PAP (DiaSys) pada Pengukuran Berbagai Panjang Gelombang

\begin{tabular}{|c|c|}
\hline Panjang gelombang $(\mathrm{nm})$ & Absorbansi \\
\hline 405 & 0,102 \\
\hline 500 & 0,484 \\
\hline 546 & 0,336 \\
\hline 578 & 0,202 \\
\hline 630 & 0,042 \\
\hline
\end{tabular}

Tabel 3 menunjukkan bahwa pada panjang gelombang $500 \mathrm{~nm}$ dengan operating time (OT) 10-15 menit diperoleh absorbansi glukosa maksimum. Dengan demikian penyerapan sampel glukosa darah untuk selanjutnya dilakukan dengan menggunakan panjang gelombang $500 \mathrm{~nm}$.

Uji Efek Penurunan Kadar Glukosa Darah: Uji efek antidiabetes dilakukan dengan metode toleransi glukosa oral (Anonim, 1993), yaitu hewan uji dibebani glukosa untuk melihat pengaruh terhadap toleransi glukosa tanpa merusak pankreas hewan uji. Pembebanan glukosa dilakukan sebelum perlakuan sehingga hewan uji akan mengalami hiperglikemia setelah pembebanan glukosa.

Obat oral antidiabetes yang digunakan sebagai pembanding adalah acarbose (glucobay ${ }^{\mathrm{R}}$, Bayer) yaitu golongan inhibitor alfa glukosida, yang didasarkan pada metode uji toleransi glukosa. Acarbose bersifat inhibitor kompetitif, yang berikatan dengan enzim alfa glukosidase dan menghambat kerja enzim dalam menghidrolisis komplek sakarida, sehingga monosakarida (glukosa) yang dihasilkan dalam jumlah sedikit dan penyerapan glukosa di usus menurun serta kadar glukosa darah tidak meningkat secara drastis.

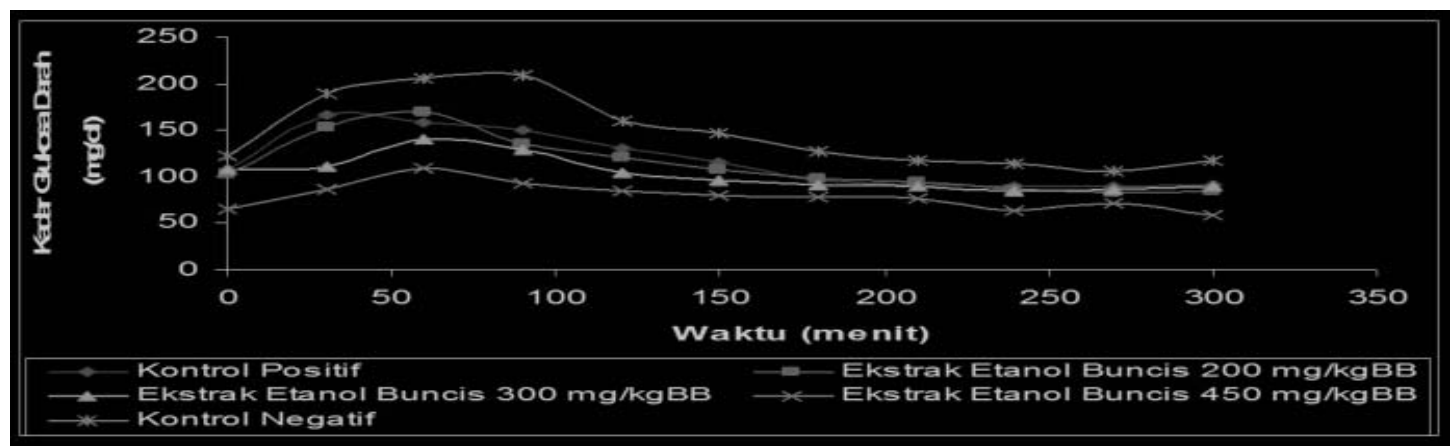

Gambar 4.Kurva Hubungan Kadar Glukosa Darah (mg/dl) terhadap Waktu Pengamatan setelah Perlakuan CMC $\mathrm{Na} \mathrm{1 \% ,} \mathrm{Acarbose} \mathrm{2,33mg/kgBB,} \mathrm{Ekstrak} \mathrm{Etanol} \mathrm{70 \%} \mathrm{Daun} \mathrm{Buncis} \mathrm{Dosis} \mathrm{200,} \mathrm{300,} \mathrm{dan} 450 \mathrm{mg} / \mathrm{kgBB}$ 
Tabel 4. Purata Kadar Glukosa Darah yang Diperoleh pada Menit-menit Tertentu pada Semua Kelompok Perlakuan $(n=4)$

\begin{tabular}{|c|c|c|c|c|c|}
\hline \multirow{2}{*}{ Waktu } & \multicolumn{5}{|c|}{ Purata Kadar Glukosa Darah (mg/dl), (x \pm SD) } \\
\cline { 2 - 6 } & Kontrol Negatif & Kontrol Positif & $\begin{array}{c}\text { Ekstrak Etanol Daun } \\
\text { buncis } \\
200 \mathrm{mg} / \mathrm{kgBB}\end{array}$ & $\begin{array}{c}\text { Ekstrak Etanol Daun } \\
\text { buncis } \\
300 \mathrm{mg} / \mathrm{kgBB}\end{array}$ & $\begin{array}{c}\text { Ekstrak Etanol Daun } \\
\text { buncis } \\
450 \mathrm{mg} / \mathrm{kgBB}\end{array}$ \\
\hline 0 & $122,40 \pm 13,17$ & $107,30 \pm 2,79$ & $103,56 \pm 30,50$ & $108,29 \pm 16,88$ & $64,68 \pm 14,60$ \\
\hline 30 & $189,48 \pm 12,61$ & $167,09 \pm 36,86$ & $152,82 \pm 28,28$ & $111,69 \pm 21,28$ & $86,79 \pm 9,94$ \\
\hline 60 & $205,76 \pm 11,60$ & $158,42 \pm 31,58$ & $170,58 \pm 24,23$ & $141,06 \pm 15,54$ & $109,22 \pm 10,39$ \\
\hline 90 & $208,87 \pm 38,23$ & $150,71 \pm 25,90$ & $135,66 \pm 18,24$ & $129,87 \pm 27,88$ & $92,87 \pm 4,36$ \\
\hline 120 & $160,54 \pm 43,22$ & $130,87 \pm 29,30$ & $121,57 \pm 17,00$ & $105,20 \pm 10,63$ & $85,39 \pm 13,64$ \\
\hline 150 & $146,81 \pm 29,53$ & $116,31 \pm 16,76$ & $108,52 \pm 18,52$ & $96,50 \pm 4,80$ & $80,48 \pm 14,01$ \\
\hline 180 & $127,36 \pm 16,48$ & $96,45 \pm 9,70$ & $97,67 \pm 11,56$ & $91,06 \pm 5,91$ & $78,94 \pm 15,41$ \\
\hline 210 & $118,01 \pm 11,73$ & $91,50 \pm 6,30$ & $94,98 \pm 11,07$ & $89,77 \pm 4,12$ & $77,13 \pm 16,64$ \\
\hline 240 & $113,87 \pm 10,79$ & $89,20 \pm 13,92$ & $86,25 \pm 17,28$ & $84,19 \pm 6,24$ & $63,68 \pm 27,78$ \\
\hline 270 & $106,93 \pm 15,80$ & $90,67 \pm 11,59$ & $83,76 \pm 14,55$ & $86,14 \pm 12,86$ & $72,21 \pm 26,78$ \\
\hline 300 & $118,15 \pm 21,05$ & $90,81 \pm 8,58$ & $84,42 \pm 4,23$ & $90,37 \pm 14,58$ & $59,08 \pm 17,42$ \\
\hline
\end{tabular}

Tabel purata kadar glukosa darah yang diperoleh pada menit-menit tertentu oleh semua kelompok perlakuan disajikan pada Tabel 4 yang menunjukkan bahwa purata kadar glukosa darah kelompok kontrol negatif paling tinggi dibanding purata kadar glukosa darah kelompok perlakuan lainnya, karena kelinci hanya diberi perlakuan CMC Na 1\%, sehingga kadar glukosa cenderung lebih tinggi. Kelompok kontrol positif, mengalami penurunan kadar glukosa darah yang rendah karena diberi perlakuan acarbose yang merupakan obat untuk menurunkan kadar glukosa darah. Kelompok sampel ekstrak etanol $70 \%$ dosis 200 , 300 dan $450 \mathrm{mg} / \mathrm{kgBB}$ mengalami penurunan kadar glukosa darah lebih rendah dibanding kontrol positif.

Nilai kadar glukosa darah digunakan untuk menghitung luas daerah di bawah kurva Area Under The Curve (AUC) setiap kelompok perlakuan terhadap waktu pengamatan, yang menunjukkan jumlah perubahan kadar glukosa dalam darah selama 300 menit, karena pengaruh perlakuan dalam setiap kelompok. Nilai purata $\mathrm{AUC}_{0-300}$ pada Tabel 5 menunjukkan bahwa yang memiliki nilai $\mathrm{AUC}_{0-300}$ paling besar adalah kelompok perlakuan kontrol negatif (CMC $\mathrm{Na}$ $1 \%)$.

Uji statistik Kolmogorov-Smirnov dilakukan setelah diperoleh nilai AUC untuk mengetahui distribusi data penelitian. Nilai signifikansi diperoleh $>0,05$ yaitu 0,868 artinya data $\mathrm{AUC}_{0-300}$ terdistribusi normal. Dilanjutkan Levene test untuk mengetahui homogenitas varian, dan diperoleh nilai signifikansi $>0,05$ yaitu 0,409 berarti data $\mathrm{AUC}_{0-300}$ memiliki varian yang homogen. Data terdistribusi normal dan homogen, dipilih analisis statistik model parametrik Anava satu jalan, untuk melihat perbedaan semua kelompok perlakuan. Berdasarkan analisis varian satu jalan, diperoleh harga signifikansi 0,000 menunjukkan adanya perbedaan yang bermakna antar kelompok $(\mathrm{P}<0,05)$. Dilakukan uji Least Significant Difference (LSD) menggunakan taraf kepercayaan 95\% untuk mengetahui kelompok perlakuan mana yang berbeda bermakna.

Hasil uji LSD $\mathrm{AUC}_{0-300}$ pada Tabel 6 menunjukkan perbedaan yang bermakna antara kelompok perlakuan kontrol negatif $\mathrm{CMC} \mathrm{Na}$ $1 \%$ dengan kelompok perlakuan kontrol positif, ekstrak etanol $70 \%$ daun buncis dosis 200,300 dan $450 \mathrm{mg} / \mathrm{kgBB}$ dengan harga signifikansi masingmasing 0,000 , berarti ke 4 kelompok perlakuan memiliki efek menurunkan kadar glukosa darah pada kelinci jantan yang dibebani glukosa. Pada kelompok perlakuan ekstrak etanol $70 \%$ daun buncis dosis 200, 300 dan $450 \mathrm{mg} / \mathrm{kgBB}$ diketahui bahwa data yang diperoleh antara dosis 200 dan $300 \mathrm{mg} / \mathrm{kgBB}$ berbeda tidak bermakna ( $\mathrm{p}=$ 0,109 ) berarti data yang diperoleh hampir sama, sedangkan data yang diperoleh antara dosis 200, $300 \mathrm{mg} / \mathrm{kgBB}$ dengan dosis $450 \mathrm{mg} / \mathrm{kgBB}$ berbeda bermakna $(p=0,001$ dan $p=0,031)$. 
Tabel 5. Nilai Purata $\mathrm{AUC}_{0-300}$ (menit, mg/dl) dari Kadar Glukosa Darah terhadap Waktu Pengamatan pada Perlakuan CMC Na 1\%, Acarbose 2,33mg/kgBB, Ekstrak Etanol 70\% Daun Buncis Dosis 200, 300, dan $450 \mathrm{mg} / \mathrm{kgBB}$

\begin{tabular}{cccccc}
\hline \multicolumn{5}{c}{ Nilai Purata $\mathrm{AUC}_{0-300}(\mathrm{menit}, \mathrm{mg} / \mathrm{dl})$} \\
\hline Perlakuan & Kelompok I & Kelompok II & Kelompok III & Kelompok IV & Kelompok V \\
Kelinci 1 & 50174,99 & 32031,93 & 34126,10 & 34273,68 & 26700,02 \\
Kelinci 2 & 44890,40 & 36211,34 & 32001,53 & 28856,75 & 26700,02 \\
Kelinci 3 & 42286,62 & 36285,92 & 32183,91 & 29592,66 & 25249,98 \\
Kelinci 4 & 42396,69 & 38301,780 & 39183,32 & 31454,43 & 26886,45 \\
$(\mathrm{x} \pm \mathrm{SE})$ & $44937,17 \pm 1846,54$ & $35707,74 \pm 1317,47$ & $34373,71 \pm 1673,72$ & $31044,38 \pm 1207,26$ & $26384,12 \pm 80,59$ \\
\hline
\end{tabular}

\section{Keterangan :}

Kelompok I Kontrol negatif (CMC Na 1\%)

Kelompok II Kontrol positif (acarbose 2,33 mg/kgBB)

Kelompok III Ekstrak etanol $70 \%$ daun buncis dosis $200 \mathrm{mg} / \mathrm{kgBB}$ )

Kelompok IV Ekstrak etanol 70\% daun buncis dosis $300 \mathrm{mg} / \mathrm{kgBB}$ )

Kelompok V Ekstrak etanol 70\% daun buncis dosis $450 \mathrm{mg} / \mathrm{kgBB}$ )

Tabel 6. Hasil Uji LSD AUC0-300 Antar Kelompok Perlakuan dengan Taraf Kepercayaan 95\%

\begin{tabular}{ccc}
\hline Antar kelompok perlakuan & Nilai P & Keterangan \\
\hline I-II & 0,000 & Berbeda bermakna \\
I-III & 0,000 & Berbeda bermakna \\
I-IV & 0,000 & Berbeda bermakna \\
I-V & 0,000 & Berbeda bermakna \\
II-III & 0,505 & Berbeda tidak bermakna \\
II-IV & 0,031 & Berbeda bermakna \\
II-V & 0,000 & Berbeda bermakna \\
III-IV & 0,109 & Berbeda tidak bermakna \\
III-V & 0,001 & Berbeda bermakna \\
IV-V & 0,031 & Berbeda bermakna \\
\hline
\end{tabular}

*P $<0,05:$ berbeda bermakna

$\mathrm{P}>0,05:$ berbeda tidak bermakna

Nilai purata $\mathrm{AUC}_{0-300}$ digunakan untuk mencari nilai persentase efek penurunan kadar glukosa darah (\%PKGD) untuk mengetahui kemampuan kelompok perlakuan dalam menurunkan kadar glukosa darah. Hasil \%PKGD terhadap nilai $\mathrm{AUC}_{0-300}$ pada Tabel 7 menunjukkan persentase penurunan kadar glukosa darah $80,14 \% \pm 0,73$ (kelompok II), 80,88\% $\pm 0,93$ (kelompok III), 82,73\% $\pm 0,67$ (kelompok IV) dan $85,32 \% \pm 0,21$ (kelompok V). Persentase terendah dihasilkan kelompok II yang secara statistik (pada Tabel 8) data berbeda tidak bermakna $(p=0,461)$ dengan kelompok. III dan berbeda bermakna dengan kelompok IV dan V dengan p 0,021 dan 0,000 . Data kelompok III dengan IV menunjukkan hasil berbeda tidak bermakna $(p=0,082)$. Data kelompok V menunjukkan hasil berbeda bermakna dengan kelompok III dan IV dengan p 0,001 dan 0,021 , yang menunjukkan bahwa kelompok $\mathrm{V}$ memiliki efek penurunan kadar glukosa darah paling besar.

Tabel 7. Persentase Penurunan Kadar Glukosa Darah (\% PKGD) Terhadap Nilai Purata $\mathrm{AUC}_{0-300}$

\begin{tabular}{lcccc}
\hline \multicolumn{5}{c}{ Nilai \% PKGD } \\
\hline Perlakuan & Kelompok II & Kelompok III & Kelompok IV & Kelompok V \\
\hline Kelinci 1 & 82,18 & 81,02 & 80,93 & 85,15 \\
Kelinci 2 & 79,85 & 82,20 & 83,95 & 85,15 \\
Kelinci 3 & 79,81 & 82,10 & 83,54 & 85,95 \\
Kelinci 4 & 78,69 & 78,20 & 82,50 & 85,04 \\
$(\mathrm{x} \pm$ SE) & $80,14 \pm 0,73$ & $80,88 \pm 0,93$ & $82,73 \pm 0,67$ & $85,32 \pm 0,21$ \\
\hline
\end{tabular}


Tabel 8. Hasil Uji LSD \% PKGD Antar Kelompok Perlakuan dengan Taraf Kepercayaan 95\%

\begin{tabular}{ccc}
\hline Antar kelompok perlakuan & Nilai P & Keterangan \\
\hline II-III & 0,461 & Berbeda tidak bermakna \\
II-IV & 0,021 & Berbeda bermakna \\
II-V & 0,000 & Berbeda bermakna \\
III-IV & 0,082 & Berbeda tidak bermakna \\
III-V & 0,001 & Berbeda bermakna \\
IV-V & 0,021 & Berbeda bermakna
\end{tabular}

Keterangan :

Kelompok I Kontrol negatif (CMC Na 1\%)

Kelompok II Kontrol positif (acarbose 2,33 mg/kgBB)

Kelompok III Ekstrak etanol 70\% daun buncis dosis $200 \mathrm{mg} / \mathrm{kgBB}$ )

Kelompok IV Ekstrak etanol 70\% daun buncis dosis $300 \mathrm{mg} / \mathrm{kgBB}$ )

Kelompok V Ekstrak etanol 70\% daun buncis dosis $450 \mathrm{mg} / \mathrm{kgBB}$ )

\section{KESIMPULAN}

Ekstrak etanol 70\% daun buncis (Phaseolus vulgaris L) dosis 200, 300 dan $450 \mathrm{mg} / \mathrm{kgBB}$ memiliki efek menurunkan kadar glukosa darah terhadap kontrol negatif CMC Na 1\% $(\mathrm{p}=0,000)$ dengan persentase penurunan kadar glukosa darah (\%PKGD) masing-masing 80,88\% $\pm 0,93$; $82,73 \% \pm 0,67$ dan $85,32 \% \pm 0,21$.

\section{SARAN}

Perlu dilakukan penelitian lebih lanjut tentang pengaruh ekstrak etanol $70 \%$ daun buncis menggunakan metode uji lain. Perlu dilakukan penelitian dengan dosis ekstrak etanol 70\% daun buncis yang lebih kecil untuk menurunkan kadar glukosa darah.

\section{DAFTAR PUSTAKA}

Anonim, 1993, Penapisan Farmakologi, Pengujian Fitokimia Dan Pengujian Klinik, Pengembangan dan Pemanfaatan Obat Bahan Alam, Jakarta.

Anonima, 2005, Diabetes Mellitus Masalah Kesehatan Masyarakat Yang Serius, (Online), (http:// www.depkes.go.id/ index.php?option=news $\&$ task $=$ viewarticle $\&$ sid $=942 \&$ itemid $=2$, diakses 22 November 2006).

Anonim $^{\mathrm{b}}$, 2005, Menormalkan Gula Darah Dengan Bahan Alami, (Online), (http:// www.republika.co.id/koran_detail. asp?id=189096\&kat_id=123, diakses 23 November 2006).

Backer, C.A., dan Van Den Brink, 1965, Flora of Java (Spermatophytes only), volume I, Groningen, The Netherlands.

Hutapea, J.R., dan Syamsyuhidayat, S.S., 1994, Inventaris Tanaman Obat Indonesia (III), Hal 201, Departemen Kesehatan
Republik Indonesia Badan Penelitian Dan Pengembangan Kesehatan.

Muhtadi, 1987, Uji Efek Ekstrak Kental Buah Phaseolus vulgaris L, Terhadap Kadar Glukosa Darah Tikus, (Online), (http:// digilib.itb.ac.id/go.php?id=jbptitbpp-gdls2-1987-ahmadmuhta-1734, diakses 27 November 2006).

Rezeki, S., 2005, Efek Hipoglikemik Fraksi Etanol 90\% Ekstrak Etanol 50\% Daun Mengkudu (Morinda citrifolia L) Pada Tikus Jantan Wistar, Skripsi, Fakultas Farmasi Universitas Muhammadiyah Surakarta, Surakarta.

Soegondo, S., Soewondo, P., dan Subekti, I., 2005, Diabetes Mellitus Penatalaksanaan Terpadu, Fakultas Kedokteran, Universitas Indonesia, Jakarta.

Subroto, 2006, Ramuan Herbal untuk Diabetes Melitus, Penebar Swadaya, Yogyakarta. 